\title{
Global forces and local currents in Argentina's sCienCe policy CROSSROADS: RESTRICTED ACCESS OR OPEN KNOWLEDGE
}

FUERZAS GLOBALES Y CORRIENTES LOCALES EN LA ENCRUCIJADA DE LA POLITICA CIENTÍFICA ARGENTINA: ACCESO RESTRINGIDO O CONOCIMIENTO ABIERTO Horacio Javier Etchichury***; Marcela Carmen Pacheco* *Universidad Nacional de Córdoba; * CONICET; etchichury74@gmail.com; marcela.pacheco@gmail.com

\begin{tabular}{l} 
Historia editorial \\
\hline Recibido: 18-11-2013 \\
Primera revisión: 09-05-2014 \\
Aceptado: 30-07-2014
\end{tabular}

Keywords

Human Rights

Science Policy; World Bank

\section{Abstract}

The article describes the tensions between two competing approaches to scientific policy in Argentina. The traditional vision favors autonomous research. The neoliberal conception fosters the link between science and markets. In the past few years, a neodevelopmentalist current also tries to stress relevance of scientific research. Finally, the article describes how the Open Access movement has entered the debate. The World Bank intervention and the human rights dimension of the question are discussed in depth. The article introduces the notion of open knowledge as a guiding criterion to design a human-rights based scientific policy.

\section{Resumen}

Palabras clave

Derechos Humanos Política científica

Banco Mundial
El artículo describe las tensiones entre dos enfoques en pugna respecto de la política científica argentina. La visión tradicional favorece la investigación autónoma. La concepción neoliberal fomenta el vínculo entre la ciencia y los mercados. En los últimos años, una corriente neodesarrollista también intenta subrayar la relevancia en la investigación científica. El artículo describe cómo el movimiento de Acceso Abierto ha entrado en este debate. La intervención del Banco Mundial y la dimensión de derechos humanos de la cuestión se debaten en profundidad. Finalmente, el texto introduce la noción de conocimiento abierto como un criterio para guiar el diseño de una política científica basada en los derechos humanos.

Etchichury, Horacio Javier y Pacheco, Marcela Carmen (2014). Global forces and local currents in Argentina's science policy crossroads: restricted access or open knowledge. Athenea Digital, 14(3), 105-127. http://dx.doi.org/10.5565/rev/athenea.1286

Scientific research in Argentina today is evolving under the influence of competing global trends. These views on the creation of knowledge constantly blend with local traditions and emerging discourses. In a permanent dialogue and tension, foreign and local ideas shape the course of science in Argentina. Global technocrats challenge national traditions, new social movements confront technocrats, human rights discourse enriches traditions, in a high-speed upward spiral movement. A thriving debate takes place at the current crossroads: the choice between restricted access or open knowledge. It is a local debate inscribed in a global context. 


\section{Introduction}

In Argentina, traditional academic culture favors autonomous research, free from market forces or political pressures. Public universities, for instance, have legally-granted academic and institutional autonomy since the mid-1880s, through Ley 1597 (also known as Ley Avellaneda, approved in 1885). In 1994, this principle was inserted in art. 75.19 of the Argentinean Constitution.

Ideally, researchers should pursue their own agenda to advance knowledge in their fields. The only accepted interest is the interest of knowledge itself, not market demands or commercial demands. Of course, many scientific developments may be applied in profitable ways, but this should not be the guiding interest.

In Argentina, scientific knowledge is traditionally created in public-funded institutions, usually linked to public universities. All results are to be realeased into the public domain, or distributed through scientific journals which circulate among institutional libraries, open to the public (Korsunsky and Campero, 2012, p. 285). Argentina's scientific research system is decentralized. A large portion of research is carried out at public universities, and the rest takes place at independent public centers loosely coordinated by CONICET, the National Council of Scientific and Technological Research, created in 1958. CONICET's 7000 researchers are spread all over the country, and a significant share of them work at the same time for a public university. There are a few more centers that belong to the Executive branch, such as the National Commission of Atomic Energy (Spanish acronym: CNEA) and the National Institute of Agricultural Technology (Spanish acronym: INTA), among others.

Researchers rely on public funding in order to achieve the highest possible degree of autonomy from market forces. Their personal income does not vary according to their fields of inquiry, so they can be true to their scientific interests, though they usually know their discoveries may have economic or strategic importance. Even in times of severe economic crisis, when public funding decreased to minimum levels, most researchers did not turn to markets in order to finance their projects. There were no significant systems for private financing of research activity. They sought other solutions: some applied for foreign aid, some others established a partnership with nonprofit organizations. In extreme cases, some reduced or ceased their research activity. Yet also in times of prosperity public funding appears to be scarce. Even in the Latin American context, Argentina's researchers are generally underfunded (Thorn, 2005, p. 12) and face inadequate conditions and complex regulations.

To enjoy autonomy, researchers also require the highest possible degree of freedom from political pressure. They should not be forced to accommodate their work to 
prevailing political currents. This is difficult, since public funding implies some degree of contact with politics. In the past, Argentina has undergone periods of extreme political repression, which severely attacked research autonomy. In the 20th century, several dictatorships ruled the country and established oppressive controls over universities and research institutions, as part of an autocratic regime. Specially in the late 1970s, hundreds of scholars had to leave the country, while many others disappeared or were executed with no fair trial, in a context of State terrorism. This cruel and brutal witch hunt sought to destroy the notion of independent, socially-oriented scientific research and to prevent the questioning of conservative principles in moral, social and political issues (Hurtado, 2010).

Since the return of democratic rule, in 1983, conditions for political autonomy have significantly improved. Universities have returned to their regular self-government where faculty members, students, graduates and employees share decisionmaking powers through collective organs which determine all matters, both institutional and academic. Other public research institutions enjoy a high level of political autonomy.

In sum, public funding and insulation from political parties and factions are the two pillars of the traditional vision on autonomous academic research. These two conditions are, in general, currently present in public universities and research institutions. Today, $60 \%$ of researchers work at public universities (Korsunsky and Campero, 2012, pp. 283-289). Only 13\% are private employees. Private universities, in particular, account for just $2 \%$ of total research and development expenditures, according to 2004 data (Thorn, 2005, p. 11).

\section{Critical views on traditional autonomy}

The ideal of "autonomous research", commonly accepted as it may be, has not been free from criticism. Sometimes autonomy has been described as a lack of connection with real social needs. People in and out of the research community have expressed their concern about the social relevance of research. The image of an "ivory tower" has been repeatedly used to accuse scholars of being out of touch with society. This is particularly important in the case of public-financed institutions. According to some critics, these institutions should be focusing on popular needs and demands. This criticism usually comes from left-leaning or progressive scholars. Oscar Varsavksy (1969/2010) wrote a seminal, influential article on this issue. This author also highlights that scientists in Latin America have no actual autonomy from central countries' scientific agendas. Argentinean astronomers, for example, often try to fit their work in broader projects, probably Europe- or US-based. Their findings have to be published in North- 
ern-hemisphere English-language indexed scientific journals. Their most prestigious colleagues work in central countries. Scientific networking leads Argentina's astronomers to engage in foreign projects, even if they have little or no relevance for Argentina's scientific agenda. In addition to that, in many cases scientists themselves migrate to central countries, in a process long known as brain-drain. Professional corporations, even at the domestic level, can also influence scientific agendas, affecting autonomy in ways that seldom become explicit.

\section{A new model: productive science, marketable research}

In the past twenty years, a new paradigm has been imported. Against traditional views, this model argues that research should focus on market needs. Science should be used to solve production problems. Knowledge is an element in the production process. Autonomy from the market is not a condition for sound research. To the contrary, only an adequate connection with markets makes sure science is on the right track. These ideas started as part of the "Washington Consensus", a core set of neoliberal policies promoted by the international financial institutions as the only way to achieve sustainable economic growth.

After Argentina's 2001 default crisis, neoliberal policies were explicitly replaced by a "neo-developmentalist" or "post-neoliberal" agenda. Yet the "productive" approach to science survived the demise of the neoliberal experiment.

Since 2003, a center-of-left government favors a partnership between public agencies and private businesses to advance national development. This shows a different conception about the role of markets. Current policies foster internal markets and domestic consumption as growth- and job-generating forces. Local businesses and Stateowned enterprises deserve special support through the incorporation of scientific and technological advances. Science and technology should contribute to a higher addedvalue production. In this way science becomes a strategic tool for economic development.

Potential economic relevance is gradually becoming an evaluation criteria for researchers and research institutions. Its relative importance is increasing over time. In other words, advancement of knowledge per se is not the only relevant objective. Research has to be useful for productive processes. To some, there seems to be a link with progressive demands for "social relevance" of science. Yet it is not always the case: what is relevant to society at large may not necessarily be relevant for markets. Production needs and market demands are the key concepts under this approach. 
In the 1990s, a new scheme to finance higher education was included as an element of this general approach that linked science to production and markets. Universities should fund themselves at least partially through marketable research. The creation of knowledge with economic potential would give universities the chance to get new additional resources. This, in turn, would enable governments to save in research budgets, a necessary step in the context of structural adjustment programs and austerity plans.

In more recent years, the emphasis in getting in touch with domestic markets aims at a different purpose. Universities are not expected now to finance themselves through their research. In the context of a decade of sustained growth (2003-2012), Argentina actually increased its science and technology expenditure. Between 2003 and 2008, it went from $0,28 \%$ to $0,36 \%$ of the Gross Domestic Product (GDP) (Korsunsky and Campero, 2012, p. 278).

Now the objective is to put knowledge into the productive cycle. Science is to be linked to productive uses. Technology appears to be as important as basic science. Argentina's government created in 2007 the Ministry of Science, Technology and Productive Innovation. This denomination is a clear sign of the new model: science follows its way apart from education, and gets connected to technology as applied, productive science.

Under this new model, autonomy from the market may be affected, since scientists are encouraged to look for guidance in the market and its needs.

\section{A cultural change}

This approach requires to turn knowledge (or at least some parts of it) into a commodity. Intellectual property systems and patent law are the main instruments to transform research outcomes into marketable objects that can be bought and sold.

Such a proposal seems to be an attractive alternative in times of economic scarcity, which have been frequent under Argentina's recurrent fiscal crises. In the event of a new crisis, public universities could find additional resources through partnerships with corporations in need of cutting edge research. American universities are usually displayed as an example of this model. In the US, the 1980 Bayh-Dole Act granted universities the ownership of inventions created in these institutions, and the right to negotiate license terms with private investors (Loise and Stevens, 2011, p. 186).

To implement this model, a cultural change is needed. The World Bank, among other relevant actors, has promoted it in its reform projects. 


\section{The World Bank: global ideas and resources to transform local culture}

The Bank has fostered this change in Argentina not only through loans but also through concepts. It has remarkable resources, both intellectual and financial.

The Bank defines itself as a "knowledge Bank", and it has become a "teaching institution" that makes extraordinary research and dissemination efforts. Yet some critics highlight it does not pay enough attention to other institutions' work on development issues. Most economists at the Bank, in spite of their diverse national origins, come from the same academic environment, namely, graduate schools of US universities. This leads to an insufficient exploration of policy alternatives (Fine, 2002, pp. 205209). The Bank's publications are, for the most part, self-referential, and previous works or local research are usually neglected. There is not enough contact with diverse positions. Through these publications, the Bank keeps remarkably visible in the public sphere. Bank research usually gets legitimacy from the international market of academic journals (Sindzingre, 2004, pp. 166-168). Through its published work, the Bank also gives borrower countries new reasons for borrowing. New concepts and topics come into play, opening the way for new programs and loans. As a development institution, the Bank offers the financial resources to carry out its projects and proposals. By combining highly-skilled technicians, ideas and money, the institution is an important part of international technocracy. The Bank's global influence can be seen in the volume of resources it lends: between 15 and 25 billion dollars each year, while the United Nations Development Program expends less than 3 billion (Killinger, 2003, p. 74; World Bank, 2007, p. 76). Typical borrower countries are middle-income nations who can also access private capital markets. During the 1990s, the Bank lost financial influence, because of the increase in private capital flows to developing countries (Ghazi, 2005, p. 36).

Decision-making procedures at the Bank do not follow a democratic model, since voting power depends on each country's number of shares. Richer countries have more influence in the institution. Formally, the highest Bank authority is the Board of Governors (one for each member country; usually, finance ministers). Since this Board meets only once a year, most attributions are delegated in a 24-member Board of Executive Directors. Each of the five largest shareholders (UK, USA, Japan, Germany and France) appoints one Executive Director. All other countries group themselves in constituencies, and they combine their voting power to appoint one executive director to represent all of them (Ghazi, 2005, p. 21; World Bank, 2007, p. 8). This Executive Board meets usually twice a week. It approves loans and makes all major policy decisions. Richest members hold decisive power in this crucial board. 
Some unsettling elements appear in the Bank's institutional life. Several internal reports have exposed and criticised "loan approval" culture and lack of effectiveness of many Bank projects. Willi Wapenhans (1992), in a well-known internal report, explains that over one-third of Bank projects had failed according to the institution's own criteria. A failed project, on the other hand, always implies a financial burden on the borrowing country (Rich, 2002, pp. 27-28). Among Bank staff, the main concern is to get the Executive Board to approve a project. The Bank's culture rewards lending targets and quick lending approval ("getting a project to the Board"), rather than development effectiveness or concrete results. An employee's promotion is based on the size (in money lent) and number of projects which were approved by the Board. In this context, existing safeguard policies (to protect the environment or indigenous peoples' rights, for example) appear as obstacles to loan approval, and as time-consuming tasks that reduce opportunities for promotion. In preparing a project, task teams have incentives to exclude safeguard policies as much as possible. Project managers are allowed to harmonize these policies and other objectives (Sarfaty, 2009, pp. 668-670), which may simply mean to give the former a secondary, subordinate status.

The reform of not-for-profit, public-funded research institutions has been in the Bank's agenda for a long time. Different projects have been put in practice in the past decades, always promoting a cultural change in the academic and scientific community. In its 1998-1999 World Development Report, the Bank recommended public-financed research should focus in productive needs. Labs should adopt a business-like structure and should seek private firms' support (World Bank, 1999, p. 147).

\section{The neoliberal period}

Since the late 1980s, Latin American universities experienced various reform programs, all of them based on neoliberal tenets (García Guadilla, 2003). The general trend of these reforms can be described as the mercantilization of universities (Santos, 2010). In 1995, the Bank sponsored a new higher education law for Argentina, as part of a far-reaching structural adjustment program. The law (Higher Education Law, or Ley 24.521) promotes the link between universities and the market. It enables universities to engage in service provision, and to establish "Social Councils" (art. 56), which may include members from the business community. Autonomy from the market is replaced by a new, opposite concept: the institutional connection with the market.

However, the law did not completely modify the prevailing academic culture. Except for a few initiatives, most scientific research today remains not directly linked to the market. A 1990 law (Technological Innovation Law, or Ley 23.877) provided a gen- 
eral framework to establish private technology-transfer offices at public institutions (including universities), but very few of them were created, and they did not attain the expected transformations (Naidorf, 2005, pp. 118-119). Social Councils did not develop.

On the other hand, competitive mechanisms to assign public research funds were successfully established (Korsunsky and Campero, 2012, p. 286). In order to compete, researchers are rated according to their merits, including the number of articles in scholarly journals. This nationwide assessement takes place every four years. The results bear decisive relevance in the competition for research funds.

Graduate studies, in turn, showed an astonishing expansion under the Banksponsored law. Between 1999 and 2005, more than 1500 graduate programs were created (Mazzola and Napoli, 2009, pp. 4-5). Seventy-five percent of graduate programs belong to public universities. Most of them cater to professional market demands: they have to be attractive for professional groups in order to achieve financial sustainability through tuition. This market orientation has been described as a cultural change, with lasting consequences (Rubinich, 2001). Undergraduate studies remain tuition-free.

\section{After the Washington Consensus}

The Bank is also present in the post-neoliberal period. In 2009, the Bank approved a 150 million US dollars loan to Argentina in order to "unleash productive innovation" (loan 7599-AR). The project included two important reforms. First, universities are strongly encouraged to subject their research to restrictive intellectual property rights, as a way to make commercialization possible. Second, a new professional group, known as "technology brokers" and "technology managers", will build the bridges between researchers and businesspeople.

The loan includes several objectives: developing human capital for productive innovation, supporting knowledge-based start-ups, improving infrastructure and enhancing policy and institutional frameworks for innovation. As we said before, the project aims to create industry-academia linkages, and encourages the commercialization of research ideas. The Bank's background report criticizes the traditional notion of autonomous research: "Argentina's higher education system is inward looking with activities often disconnected from the needs of the industry and the economy at large" (World Bank, 2008, p. 29). In a 2005 working paper, World Bank staff emphasized the need to "enhance the relevance of public research for society and the private sector", because public institutions were "not sufficiently responsive to the needs of industry" (Thorn, 2005, pp. 7, 18). The loan is an instrument to modify, at least partially, this academic culture. 
To help universities abandon the traditional model, the loan provides financing to implement "international best practice models for the management and commercialization of intellectual property" (World Bank, 2008, pp. 15-16). Best practices in this field are imported from abroad. The Ministry of Science, Technology and Productive Innovation would assist technology transfer offices at public universities to achieve this goal. The 2005 World Bank working paper already described the lack of a strong intellectual property rights regime as one of the weaknesses in Argentina's scientific system (Thorn, 2005).

Twelve million dollars are assigned to the creation of six graduate programs at public universities to train "technology brokers" and "technology managers". These managerially-trained professionals should also have a solid understanding of scientific questions. Their mission is to "create links between research centers and companies" (World Bank, 2008, p. 54).

To sum up, the Bank uses its financial leverage to promote a cultural change. It fosters the adoption of a new legal framework (intellectual property rights) and the creation of a new professional group (technology brokers and managers). These elements contribute, or so the Bank expects, to shape a new academic culture, where market needs and demands will drive scientists' efforts.

\section{The convergence with local policies}

The Bank, as an external force, promotes a set of measures that Argentina's government also supports under its own development plans. Any World Bank loan needs to be agreed with the borrower country. In general, this negotiation takes place under an institutional arrangement that favors the major shareholders. Any loan has to be approved by the Executive Board, where developed countries hold decisive voting power (Ghazi, 2005, pp. 250-251; World Bank, 2007). In the present global context, some developing countries, such as Argentina, may be enjoying a stronger bargaining position.

In the case of this loan, a complex process seems to be taking place. On the one hand, the Bank promotes its long-held agenda of pro-business reforms in the field of science. Argentina's government, in turn, seizes the opportunity to advance its own conception about scientific research. This vision favors the connection between research and industrialization, export diversification and increase in added-value production. In March 2013, Argentina's Ministry of Science, Technology and Productive Innovation launched Argentina Innovadora 2020 (Ministry of Science, Technology and Productive Innovation, 2013), a comprehensive national plan to foster scientific and 
technological innovation. The plan includes, once again, the reform of intellectual property regulation as a crucial instrument. The expansion of intellectual property is also described as a protective tool against "free-riders": it may prevent foreign firms from using local universities' research at no cost. As a general vision, the government holds that public universities should be inscribed in a national development project. This is not the only alternative. A different approach would entrust other State institutions to perform these connections. For instance, the National Institute of Industrial Technology, or the National Institute of Agricultural Technology, which do not cherish autonomy from market demands as part of their institutional values.

\section{An opposite trend: the Open Access unexpected coalition}

While this cultural reform project is on its way, a growing movement favors a different approach: open access to knowledge. Although rooted in local traditions and criteria, this burgeoning movement also has links to global trends, which have also strong presence in Latin America.

Open Access (OA) is a way to regulate access to publications and materials, including texts, images, or music, among other possibilities. Under this model, authors grant the public the right to have access to the material free of charge, to reproduce it in full or partially, and to distribute it through various means, sometimes including commercial distribution. These permissions are not necessary when materials are already in the public domain. Regular commercial publishing, on the other hand, keeps all these liberties in the hands of publishing houses. To access the content of a book, for instance, readers have to pay a fee (usually, the book price). This does not entitle them to translate it, copy it or distribute it, with or without commercial gain. OA features are roughly defined in three international statements, issued in Budapest (Budapest Open Access Initiative, 2002), Bethesda (2003) and Berlin (2003). The latter has a salient status, since it was sponsored by the Max Planck Society. By May 2014, almost 480 scientific organizations have signed the declaration. In 2005, a significant development takes place in Latin America. A special declaration on Open Access is issued in Salvador de Bahia (Brazil), entitled "The developing world's prospective". (Declaración de Salvador sobre "Acceso Abierto", 2005) This declaration stresses the need to promote equity and the pioneering role of developing countries in launching open access policies.

New technology has made open access possible. Digitalization and the ever expanding reach of internet offer the basis for a large-scale implementation of OA. Pub- 
lishing online gives every person with internet access the possibility to get in contact with academic materials, to reproduce and distribute them all over the world, at virtually no cost (Suber, 2012).

Academic and scientific production is particularly suitable for OA. Authors in this area usually have no profit motivation, and they are not paid for their pieces. They publish to have an impact in their field of expertise and, as a consequence, to advance their careers. OA offers an attractive alternative: scholarly articles can be read by more people once the economic barrier is removed and the ban on free reproduction and distribution is lifted. OA does not affect the academic peer review system. Almost all editors and referees do not receive payment from the journals. The absence of access fees does not prevent them from performing their task.

Latin America is one of the leading regions in implementing OA policies, as can be seen by citing a few relevant examples. At a regional level, CLACSO (Spanish acronym for the Latin American Council of Social Sciences) offers an OA digital library with over 30,000 full-text papers and books. Brazil's Scientific Electronic Library Online (Scielo) provides another remarkable example. La Referencia, in turn, launched its website in 2012. It is a federation of scientific repositories from nine Latin American countries, sponsored by the Inter-American Development Bank. Another significant virtual library is Redalyc, which gives full access to more than 300,000 articles from scientific journals based in Latin America, Spain and Portugal. The National Autonomous University of Mexico (Spanish acronym: UNAM) has launched an ambitious OA initiative, called Toda la UNAM en línea (Spanish for "The complete UNAM online"). Described as a permanent program and as an official OA policy, this initiative makes every university resource available to the general public at no cost through a special website, but also on Twitter and Facebook, where books, photographs, music, paintings, scientific records and many other elements can be easily accessed. In almost every Latin American country one or more digital repositories are currently working. In another evidence of the importance of these regional developments, UNESCO has recently published a report (2013) on a consultation with experts from Latin America and the Caribbean on open access policies. In addition to that, OA is part of alternative political proposals in Latin America. For instance, in the past few months, Ecuadoran government started its FLOK Society Project. FLOK stands for "Free Libre Open Knowledge": the project includes the creation of a knowledge commons, in order to achieve a social economy of knowledge. 


\section{Social production, unrestricted access}

Different strands of this movement share a common question: why should socially created goods (like science and culture) be subject to private appropriation and commercial distribution? (Pirie, 2009). Elinor Ostrom pioneered a fresh approach to these issues by starting to look at knowledge as a commons, "a resource shared by a group of people" (Hess and Ostrom, 2007, p. 4). In addition to that, it is not easy to exclude others from knowledge and one person's use of it does not affect other people's capacity to do the same. These features led Ostrom to define knowledge as a common good, sometimes called "the knowledge commons" or "the commons of the mind".

Those who favor a commons-based approach dispute conventional wisdom, pointing out that there is no empirical evidence that current intellectual property systems actually foster innovation (Shaver, 2010, pp. 159-160). Economic efficiency is the main argument in favor of restrictions to access. Yet it has no clear scientific base in relevant literature. On the other hand, expanding access offers clear social benefits. Knowledge, as a resource, actually increases when it is shared. New ideas build upon previous ones, collaboration brings to life fresh creations. As said a few lines before, more and more people can enjoy any element of culture, and this does not prevent other people to enjoy the same element. This is termed "nonrivalrous consumption". Exclusion is artificial: intellectual property law restrictions are the instrument to achieve it.

\section{Historical roots and new partners}

The open access approach is not entirely new. It recreates a long-standing tradition in the context of information technologies. In fact, the 2002 Budapest declaration stresses this in its first sentence: "An old tradition and a new technology have converged to make possible an unprecedented public good" (Budapest Open Access Initiative, 2002, paragraph 1). In the case of Argentina, as in many other countries, traditional views on knowledge have long been based in openness and access. Academic culture, as explained before, favors unrestricted access and distribution. There is something pleasantly familiar in the open access model. It expresses, under a new technological framework, a long-held view on how to generate and distribute knowledge.

At the same time, this tradition is enriched with new voices and new concepts. Many of them also come from global movements.

Free software activists contribute to the open access approach. Software is, like literature or music, a cultural expression, not a physical product. It is a technical lan- 
guage, used to express and communicate algorithms, $i$. e., step-by-step sequences of tasks to be performed by a computer. Usual copyright restrictions turn out to be excessive in the case of software. For instance, if a piece of music becomes part of the public domain 70 years after its creator's death, that piece of music may still have cultural relevance. But software becomes obsolete in a very short period of time. A 70-year protection makes software useless by the time it gets into the public domain. In addition to that, software is usually distributed in machine language, not readable by humans. This makes it impossible for the software community to learn from each other, just like musicians or writers do by having contact with copyrighted works (Heinz, 2010a).

The free software movement is based on a different set of principles. Software creation is conceived as a collaborative endeavor, open to any person who wants to participate. Work is radically decentralized. Every new creation can be improved or reshaped, every improvement benefits the whole community. By using the appropriate licenses, free software creations cannot be subject to restrictive intellectual property rights: they have to be distributed under the same conditions (Heinz 2010b). A software is free if it grants its user with four basic freedoms: 1) the freedom to run the program; 2) the freedom to study and modify the program, which requires access to the source code; 3 ) the freedom to distribute copies; 4) the freedom to distribute copies of your modified version, free of charge or charging a fee (Free Software Foundation, 2013). Based on these ideas, the movement has given birth to countless applications increasingly used in computers all over the world. This approach, again, shares relevant features with the classic scientific attitude: new ideas are based in previous knowledge and they are the basis for future discoveries; barriers to knowledge are artificial.

A similar philosophy inspires health rights activists in their fight against restrictive regimes over medicines. In the process leading to the creation of the World Trade Organization (WTO), industrialized countries promoted the Agreement on Trade-Related Aspects of Intellectual Property Rights (TRIPs). This treaty sets the minimum standards all countries must follow in their local intellectual property laws, including patent law (Correa, 2000). In many cases, this means life-saving medicines are subject to patent regimes. Patent holders can set prices at their convenience. Steffen Guise, Wang and De Campos (2008) have studied this issue in the Brazilian experience. In the late 1990s, a vibrant debate arose about access to medicines in extremely poor countries, specially HIV-affected African nations. As a result of increasing political pressure, developing countries sponsored the 2001 Doha Declaration, establishing some interpretive guidelines. The declaration grants any country the right to protect public 
health and to ensure access to medicines, including the right to issue compulsory licences. Under this mechanism, a country can authorize local companies or state agencies to start manufacturing patented medicines, if a public health emergency arises. Other countries require high standards of innovation in order to grant new patents for medicines. India offers a clear example. In April 2013, India's Constitutional Court confirmed the constitutionality of this framework and dismissed the legal challenge initiated by Swiss pharmaceutical company Novartis.

Argentina joined the WTO and reformed its patent law accordingly in the 1990s. Yet an alternative, health-centered view sits comfortably with human rights and the constitutional framework, which grants the right to health. A long line of Supreme Court cases, starting in 2000, have firmly recognized not only the right to health, but also the State's comprehensive responsibility in fulfilling this right (Bergallo, 2011). Following this reasoning, restrictive patents cannot pose barriers against health needs. Human rights discourse provides valuable arguments in favor of open access, as we will see below.

The expansion of intellectual property rights also faces opposition from environmental activists. In particular, several movements fight the patenting of living creatures or genetic information, specially in the case of seeds (Busaniche, 2009, pp. 34-38). Privatization of nature and of ancestral knowledge may severely impact on the livelihood of small farmers and peasants, and in food prices.

\section{A matter of rights}

Human rights discourse contributes relevant, compelling arguments in favor of open access. The right to science and culture offers a sound base for such an approach. This right is granted in art. 27 of the 1948 Universal Declaration of Human Rights (UDHR), and in art. 15 of the 1966 International Covenant on Economic, Social and Cultural Rights (ICESCR). According to these international documents, every person has the right freely to participate in the cultural life of the community, to enjoy the arts and to share in scientific advancement and its benefits. In addition to that, everyone has the right to the protection of the moral and material interests resulting from any scientific, literary or artistic production of which he is the author (International Covenant on Economic, Social and Cultural Rights, 1966). This second element, of course, does not require the adoption of restrictive intellectual property systems and decades-long monopolies, like those sponsored by the WTO. As the UN Committee on Economic, Social and Cultural Rights (2005) has established, authors' rights protect only the access to an adequate standard of living, including the enjoyment of all social rights for any author or creator. The Committee also argues that current intellectual property rights 
are not actual authors' human rights, since they are usually exercised by large publishing companies. The 2009 Venice Declaration (Venice Statement on the Right to Enjoy the Benefits of Scientific Development and its applications, 2009), signed by a group of human rights experts gathered by UNESCO, stresses that the right to scientific progress and its applications:

May create tensions with the intellectual property regime, which is a temporary monopoly with a valuable social function that should be managed in accordance with a common responsibility to prevent the unacceptable prioritization of profit for some over benefit for all (2009, p. 15).

$\mathrm{OA}$ is also a relevant instrument to ensure full enjoyment of the right to education, also granted in the UDHR and the ICESCR. This right includes not only elementary education, but also higher levels, including university education (ICESCR, 1966 art. 13). At the same time, taking commons as an operational framework is also related to a relevant UDHR clause: in art. 17 (1948), the Declaration grants every person "the right to property as the right to own property alone as well as in association with others". In other words, collective property is also a human right. The "knowledge commons" concept is protected under a human rights approach.

In Argentina, the 1948 Declaration and the 1966 Covenant have constitutional rank and binding force. The 1994 Constitutional Convention endowed nine human rights treaties with constitutional rank, through art. 75.22 (Argentinean Constitution, 1994; Argentinean Constitution Official English-language, 1994). The same provision includes a Congressional procedure for the removal of these treaties from the constitutional framework, and for the incorporation of new human rights treaties. Both operations require supermajority votes in both houses of Congress. The Constitution includes now explicit language from international human rights law, which has to be harmonized with the rest of the Constitution, since all these elements share an equal rank. Therefore, Argentina grants some human right treaties constitutional status (Koven Levit, 1999), in addition to Argentina's commitment at the international level. Even if these treaties were not part of the Constitution, they would remain applicable. All ratified treaties are part of Argentinean legal system; they have a rank higher than that of ordinary statutes, according to arts. 31 and 75.22. The 1966 ICESCR, for instance, was ratified by Argentina on August 8th, 1986.

Human rights discourse currently has a central place in the public sphere. A large group of public policies in recent years have been explicitly based in human rights. These policies include the approval of same-sex marriage (Vaggione, 2011), the criminal prosecution of massive human rights violations committed by the military in the 1970s (Human Righs Watch, 2012), and the adoption of a large-scale conditioned cash 
transfers program for families with children (known as Asignación Universal por Hijo, Spanish for Universal Child Allowance, Bertranou and Maurizio, 2012; World Bank, 2009). References to human rights in the public discourse now cannot simply be dismissed or neglected. Restrictive intellectual property schemes amount to a State-sponsored artificial barrier that prevents full access to science and culture (Shaver, 2010, p. 172). They affect a human right. The UN Committee's General Comments are also binding for Argentina's judiciary in applying human rights standards.

Under this approach, the World Bank recent proposal on productive innovation in Argentina appears to be against the right to science and culture. The Bank does not take human rights as a binding limit in policy design (Darrow, 2003; Ghazi, 2005). Therefore, its proposals are not always consistent with international legal obligations based in human rights conventions.

The Bank argues human rights are beyond its mission. It describes itself as a technical institution, with a non-political mandate. This has a crucial importance to keep the Bank's apolitical and technical image, which allows the Bank to raise its funds in capital markets (Killinger, 2003, p. 3). Galit Sarfaty (2009) argues that there is no clear consensus among international law scholars on the Bank's legal obligations under international human rights law. The Bank, in turn, has always favored a restrictive interpretation of its Articles of Agreement. According to Stefanie Killinger (2003), the Articles do not prevent the Bank from extending its mission to include civil and political rights; but at the same time the Articles do not require the Bank to do it, except for the small number of human rights standards known as ius cogens. In turn, the General Counsel's office at the Bank has gradually expanded the mandate to include social and political dimensions of development, anticorruption programmes and judicial reform projects (Sarfaty, 2009, pp. 658-659). So, while the Bank argues it cannot include human rights considerations in its programmes because of its Articles of Agreement, it has given a significant weight to the clearly political notion of "good governance" (Klein, 1999, p. 105).

Unlike other institutions such as UNESCO or UNICEF, the WB has not released any Operational Policy on human rights (Ghazi, 2005, p. 60). According to Sarfaty (2009), human rights are still a marginal issue at the WB. There is no staff policy to reduce the impact of any project on human rights. In engaging in policy dialogue with a member country, no requirement is made to take into account the borrower nation's obligations under international human rights law. Finally, there is no rule about which level of human rights violations would trigger the suspension of Bank activities at a certain country. On the other hand, there is an increasing demand to include human rights considerations in the Bank's projects and programs, especially when other UN 
institutions are already doing so in their own work. Even private banks pay attention to this issue, in order to keep an acceptable public image.

Argentinean lawmakers, in turn, have recently taken a significant step. In November 2013, Argentina's Congress unanimously passed the Digital Repositories Act (DRA), or Ley 26.899. This statute requires all public research institutions to create OA digital repositories. According to the bill, researchers at public institutions must post a copy of their work in the institutional repository within six months of final approval or publication. Yet the bill makes an important exception: it does not include works subject to industrial property rights or to specific contracts with third parties. The bill could actually foster contracts with private publishing houses to put a work out of the bill's reach before it is finished. But at the same time, the bill contains explicit language in favor of OA, and it ensures that most of researchers' work comes under that regime. Argentina's statute is part of a greater movement. A few months earlier, in June 2013, Peru passed its own digital repositories legislation, becoming the first Latin American country to do so. Mexico, in turn, approved a digital repositories act in early 2014.

The move towards open access in Argentina was already taking place. Though comprehensive data are not yet available, several reports show that $70 \%$ of all Argentinean scientific publications included in Scopus have been published in open access journals or repositories. Many universities already have established or are about to establish institutional repositories. There are more than 20 operating repositories which belong to higher education or research institutions (Miguel, Gómez \& Bongiovani, 2012).

\section{A policy crossroads, a cultural turning point: from restricted access to open knowledge}

A decisive transformation is under way. Technology has opened alternatives unknown before, and brings to life new debates. The sense of this transformation is being defined in the complex interaction between these two large movements. One favors stronger restrictions on access to knowledge and promotes the connection between science and markets. The other one takes the opposite direction, trying to prevent knowledge from becoming a commodity, or being subject to monopolistic control.

In Argentina, as in several other countries, global open access movements get in touch with preexisting academic traditions and human rights theory and practice. Out of this confluence, a deeper notion is coming to light: open knowledge. The transforma- 
tion goes beyond mere access to contents. Social inclusion and equality require more than simple access: they imply the possibility to participate, to put ideas in crisis, to build and rebuild concepts. As educational research has long shown (Tenti Fanfani, 1992), it is not enough to grant access if social and cognitive abilities are not in place in order to take ownership of knowledge. Therefore, open knowledge requires to ensure the human right to science and culture, and the human right to education.

Open knowledge is, under current circumstances, possible and necessary. The DRA makes it mandatory in a substantial area of scientific activity. Technology provides the means to distribute any piece of knowledge to almost every corner of the world, at a financially-sustainable cost. A knowledge-based society requires every community and every person to have access to science and culture. Human rights law turns open knowledge in a legal issue for the State.

The DRA is an important step in defining the road ahead. It is a political move to foster a cultural change towards open knowledge. It establishes a legal requirement to inscribe all scientific and academic production in the knowledge commons. This mandate expands the scope of such a commons, and it also prevents the private enclosure of public-funded academic activity. Knowledge circulation will not depend on market incentives or economic conditions, but on social concerns and needs, expressed through various and multiple channels, as many as civil societies may set up.

As a general policy, the DRA will have an impact across Argentina's entire scientific system. Universities will experience a specific and deep transformation in fulfilling the legal mandate. Setting up digital repositories will affect universities' three missions (to teach, to do research, to establish community linkages).

University research will enrich institutional repositories. This will not only foster future research, but it will also provide the basis for enforcing the human right to science and culture. Traditional ideas on science circulation focused in ensuring the scientific community had access to new discoveries. Under the open knolewdge paradigm, the entire human community is called to participate. Every person can exercise the right to science and culture in order to strengthen his or her own autonomy in drafting and carrying out a life plan.

All teaching materials created by universities will also be in institutional repositories. The right to education will greatly benefit from this development. Faculty members, in turn, will be able to create new materials using their colleagues' work, adapting previous creations to new environments and needs. Teachers from elementary and secondary schools may also find useful approaches in the repositories. A collective, progressive, collaborative creation has always been a part of the teaching activity. Dig- 
ital technology now offers new tools to enlarge and improve what may be termed as "the teaching commons".

Universities in Argentina, and in Latin America, are proud themselves of their linkage activities. Working with the communities to address social problems has always been a crucial part of universities' life. These programs are usually called "extension programs”. They involve not only on-the-ground activities, but also previous research. In addition to that, extension programs usually yield a great deal of materials, such as books, in-depth reports, leaflets, newsletters, brochures, documentary films, TV and radio programs, artistic works, project assessments, special teaching aids, and communication and outreach tools, among many other products. All these materials will now be part of digital repositories, offering sound basis for future extension activities, and for communities themselves to use and to adapt them to their own circumstances.

By fulfilling a legal mandate, universities will contribute to a cultural change that keeps growing. Under this new vision, people will be more aware of knowledge as a collective endeavor, and of the importance of strengthening and caring for the intellectual commons. People are entitled not only to access, but also to full appropriation. A robust conception of scientific and personal autonomy requires the right to do something with knowledge. Creation, transformation, innovation: all of them are expressions of human development and conditions for meaningful liberty to be equally enjoyed.

\section{References}

Argentinean Constitution (1994). Retrieved from: http://www.infojus.gob.ar/nacionalconstitucion-nacional-constitucion-nacion-argentina-lns0002665-1994-0822/123456789-0abc-defg-g56-62000scanyel

Argentinean Constitution Official English-language (1994). Retrieved from: http://www.biblioteca.jus.gov.ar/Argentina-Constitution.pdf

Bergallo, Paola (2011). Courts and social change: Lessons from the struggle to universalize access to HIV/AIDS treatment in Argentina. Texas Law Review, 89-7, 1611-1641. Retrieved from: http://www.texaslrev.com/wpcontent/uploads/Bergallo-89-TLR-1611.pdf

Bertranou, Fabio \& Maurizio, Roxana (2012). Semi-conditional cash transfers in the form of familly allowances for children and adolescents in the informal economy in Argentina. International Social Security Review, 65, 53-72. http://dx.doi.org/10.1111/j.1752-1734.2011.01420.x

Budapest Open Access Initiative (2002). Retrieved from: http://www.opensocietyfoundations.org/openaccess/read 
Busaniche, Beatriz (2009). Conceptos clave para comprender la problemática. In Federico Heinz \& Beatriz Busaniche (Eds.), Libres de monopolios sobre el conocimiento y la vida: hacia una convergencia de movimientos (pp. 55-58). Córdoba: Fundación Vía Libre.

Correa, Carlos (2000). Intellectual property rights, the WTO and developing countries. The TRIPS Agreement and policy options. London: Zed Books.

Darrow, Mac (2003). Between Light and Shadow: The World Bank, the International Monetary Fund and International Human Rights Law. Portland: Hart Publishing.

Declaración de Salvador sobre "Acceso Abierto" (2005). Retrieved from: http://www.icml9.org/channel.php?lang $=$ es\&channel $=87 \&$ content $=437$

Fine, Ben (2002). The World Bank's speculation on social capital. In Jonathan R. Pincus \& Jeffrey A. Winters (Eds.), Reinventing the World Bank (pp. 203-221). Ithaca and London: Cornell University Press.

Free Software Foundation (2013). What is Free Software. Retrieved from: http://www.gnu.org/philosophy/free-sw.en.html

García Guadilla, Carmen (2003). Balance de la década de los '90 y reflexiones sobre las nuevas fuerzas de cambio en la educación superior. In Marcela Mollis (Coord.), Las universidades en América Latina: reformadas o alteradas? La cosmética del poder financiero (pp. 17-37). Buenos Aires: CLACSO. Retrieved from:

http://www.ccee.edu.uy/eda/TGU/ensenian/historia univ/bALANCE DeCAD a90G.GUADILLA.pdf

Ghazi, Bahram (2005). The IMF, the World Bank and the question of human rights. Ardsley (New York): Transnational Publishers.

Heinz, Federico (2010a). Software vs. Copyright. In Beatriz Busaniche (Ed.), Argentina Copyleft. La crisis del modelo de derecho de autor y las prácticas de democratización de la cultura (pp. 75-80). Villa Allende: Fundación Vía Libre Fundación Heinrich Böll Cono Sur. Retrieved from: http://vialibre.org.ar/arcopy.pdf

Heinz, Federico (2010b). Software libre: la revolución constructiva. In Beatriz Busaniche (Ed.), Argentina Copyleft. La crisis del modelo de derecho de autor y las prácticas de democratización de la cultura (pp. 109-112). Villa Allende: Fundación Vía Libre - Fundación Heinrich Böll Cono Sur. Retrieved from: http://vialibre.org.ar/arcopy.pdf

Hess, Charlotte \& Ostrom, Elinor (2007). Understanding knowledge as a commons. From theory to practice. Cambridge: MIT Press.

Human Rights Watch (2012): World Report 2012: Argentina. http://www.hrw.org/sites/default/files/related material/argentina 2012 0.pdf

Hurtado, Diego (2010). La ciencia argentina. Un proyecto inconcluso: 1930-2000. Buenos Aires: Edhasa.

International Covenant on Economic, Social and Cultural Rights (1966). Retrieved from: https://treaties.un.org/pages/viewdetails.aspx? chapter $=4 \&$ lang $=$ en $\&$ mtdsg no $=\mathrm{iv}-3 \&$ src $=$ treaty 
Killinger, Stefanie (2003). The World Bank's non-political mandate. Berlin: Carl Heymanns Verlag KG.

Klein, Pierre (1999). Institutions financières internationales et les droits de la personne. Revue Belge de Droit International, 32(1), 97-114.

Korsunsky, Lionel \& Campero, Agustín (2012). La actividad científica en la universidad: 2003-2009, entre el financiamiento y el laissez faire. In Adriana Chiroleu, Mónica Marquina \& Eduardo Rinesi (Eds.), La política universitaria de los gobiernos Kirchner: continuidades, rupturas, complejidades (pp. 271-300). Los Polvorines (Argentina): Universidad Nacional de General Sarmiento.

Koven Levit, Janet (1999). The constitutionalization of human rights in Argentina: Problem or Promise? Columbia Journal of Transnational Law, 37, 281-351.

Ley 1597 (also known as Ley Avellaneda), University Law, approved on 26 June 1885. http://www.coneau.gov.ar/archivos/554.pdf

Ley 23.877, Technological Innovation Law, approved on 28 September 1990 (Boletín Oficial, 01.11.1990).

http://www.infoleg.gov.ar/infolegInternet/anexos/0-4999/277/norma.htm

Ley 24.521, Higer Education Law, approved on 20 July 1995 (Boletín Oficial, 10.08.1995). www.infoleg.mecon.gov.ar/infolegInternet/anexos/2500029999/25394/texact.htm

Ley 26.899, Digital Repositories Act, approved on 13 November 2013 (Boletín Oficial, 09.12.2013). http://www.infoleg.gob.ar/infolegInternet/anexos/220000224999/223459/norma.htm

Loise, Vicki \& Stevens, Ashley J. (2010). The Bayh-Dole Act turns 30. Science Translational Medicine, 52, 185-194. Retrieved from: http://www.bu.edu/otd/files/2011/02/The Bayh-Dole Act Turns 30.pdf

Mazzola, Carlos \& Napoli, Fernando (2009, November). Monedas falsas en el posgrado. Paper delivered at the VI Encuentro Nacional y III Latinoamericano La Universidad como objeto de estudio. Universidad, conocimiento y sociedad: innovación y compromiso. Córdoba (Argentina).

Miguel, Sandra; Gómez, Nancy \& Bongiovani, Paola (2012). Acceso abierto real y potencial a la producción científica de un país. El caso argentino, 2012. El Profesional de la Información, 21-2, 146-153. 53. http://dx.doi.org/10.3145/epi.2012.mar.04

Ministry of Science, Technology and Productive Innovation (2013). Argentina Innovadora 2020. Retrieved from: www.argentinainnovadora2020.mincyt.gob.ar/?page id=312

Naidorf, Judith (2005). La privatización del conocimiento público en universidades públicas. In Pablo Gentili \& Bettina Levy (Eds.), Espacio público y privatización del conocimiento: estudios sobre políticas universitarias en América Latina (pp. 101-161). Buenos Aires: CLACSO.

Pirie, Iain (2009). The political economy of academic publishing, Historical Materialism, $17-3,31-60$. 
Rich, Bruce (2002). The World Bank under James Wolfensohn. In Jonathan R. Pincus \& Jeffrey A. Winters (Eds.), Reinventing the World Bank (pp. 26-53). Ithaca London: Cornell University Press.

Rubinich, Lucas (2001). La conformación de un clima cultural. Neoliberalismo y universidad. Buenos Aires: Universidad de Buenos Aires.

Santos, Boaventura de Sousa (2010). The university of the twenty-first century. Towards a democratic and emancipatory university. Retrieved from: http://www.eurozine.com/articles/2010-07-01-santos-en.html

Sarfaty, Galit (2009). Why culture matters in international institutions: the marginality of human rights at the World Bank. American fournal of International Law, 103, 647-683.

Shaver, Lea (2010). The right to science and culture. Wisconsin Law Review, 121, 121184. http://dx.doi.org/10.2139/ssrn.1354788

Sindzingre, Alice (2004). The evolution of the concept of poverty in multilateral financial institutions. The case of the World Bank. In Morten Bøås \& Desmond McNeill (Eds.), Global institutions and development. Framing the world? (pp. 164-177). London - New York: Routledge.

Steffen Guise, Monica; Wang, Daniel \& De Campos, Thana Cristina (2008). Access to medicines: pharmaceutical patents and the right to health. In Lea Shaver (Ed.), Access to Knowledge in Brazil (pp. 165-213). New Haven: Information Society Project, Yale Law School. Retrieved from: http://www.law.yale.edu/documents/pdf/ISP/A2KBrazil bkmk.pdf

Suber, Peter (2012). Open Access overview. Retrieved from: http://legacy.earlham.edu/ peters/fos/overview.htm

Tenti Fanfani, Emilio (1992). La escuela vacía. Deberes del Estado y responsabilidades de la sociedad. Buenos Aires: Losada / UNICEF.

Thorn, Kristian (2005). Science, technology and innovation in Argentina. A profile of issues and practices (Working Paper). Washington (D.C.): The World Bank.

UNESCO (2013). Report of the regional Latin American and Caribbean consultation on open access to scientific information and research - Concepts and Policies. Paris: UNESCO.

United Nations Committee on Economic, Social and Cultural Rights (2005). General Comment 17. E/C.12/GC/17. Retrieved from: http://tbinternet.ohchr.org/ layouts/treatybodyexternal/Download.aspx? symbolno=E\%2fC.12\%2fGC $\% 2 \mathrm{f} 17 \&$ Lang $=\mathrm{en}$

Universal Declaration of Human Rights (1948). Retrieved from: http://www.un.org/en/documents/udhr/

Vaggione, Juan Marco (2011). Sexual Rights and Religion: Same-Sex Marriage and Lawmakers' Catholic Identity in Argentina. University of Miami Law Review, 65, 935-954. http://lawreview.law.miami.edu/wpcontent/uploads/2011/12/v65 i3 jmvaggione.pdf

Varsavksy, Oscar (1969/2010). Ciencia, politica y cientificismo. Buenos Aires: Capital Intelectual. 
Venice Statement on the Right to Enjoy the Benefits of Scientific Development and its applications (2009). Retrieved from: http://unesdoc.unesco.org/images/0018/001855/185558e.pdf

Wapenhans, Willi (1992). Effective Implementation: Key to development impact. Report of the World Bank's Portfolio Management Task Force. Washington (D.C.): The World Bank. Retrieved from: http://info.worldbank.org/etools/docs/library/37494/FinancialAnalysisPractice .pdf

World Bank (1999). World Development Report. Knowledge for Development. 1998-1999. Washington (D.C.): The World Bank and Oxford University Press.

World Bank (2007). A guide to the World Bank. Washington (D.C.): The World Bank.

World Bank (2008). Argentina - Unleashing Productive Innovation Project. Washington (D.C.): The World Bank. Retrieved from:

http://documents.worldbank.org/curated/en/2008/08/9831293/argentinaunleashing-productive-innovation-project

World Bank (2009). Report No 47874-AR - Project appraisal document on a proposed loan in the amount of US\$450 million to the Argentine Republic for a basic protection project. Washington (D.C.): The World Bank. Retrieved from: http://go.worldbank.org/URX1Z8NY70

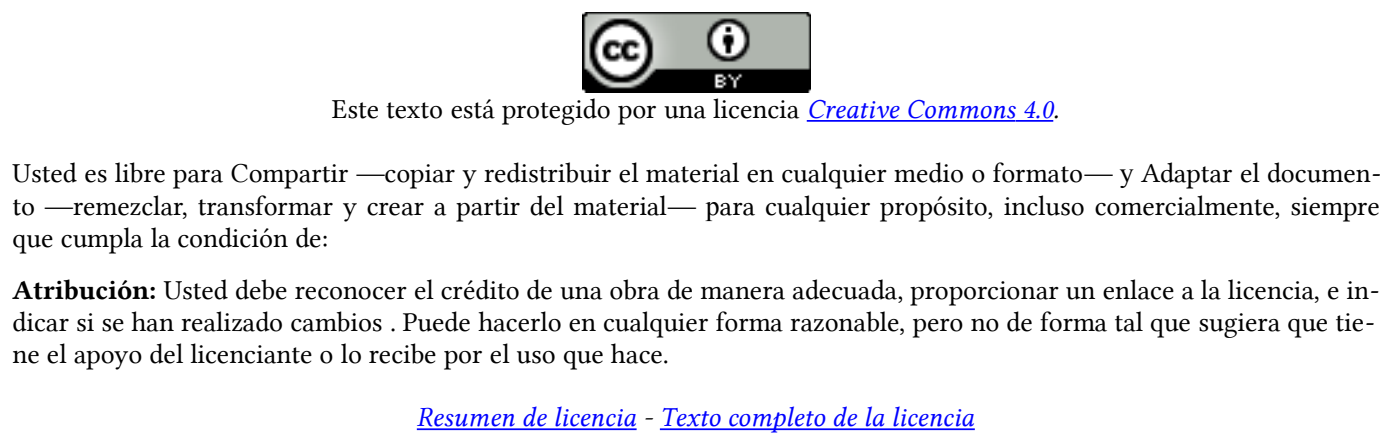

